\title{
Grieks-Romeinse apokaliptiek en die Christelike kerugma
}

\author{
H (Cules) J Boshoff \& Andries G van Aarde* \\ Departement Nuwe-Testamentiese Wetenskap \\ Fakulteit Teologie \\ Universiteit van Pretoria
}

\begin{abstract}
Greco-Roman apocalypticism and the Christian kerygma

This study aims to show that the idea of the kingdom of God can be viewed as an apocalyptic alternative to the Pax Romana. The apocalyptic thinking of the Roman Empire had a profound influence on the kerygma of Jesus and his followers. Therefore, the kingdom of God came to replace the Pax Romana and this replacement took form in the kerygma of Jesus Christ. It is the view expressed in this study that the Christian view of the kingdom as a present-day reality derived from the apocalyptic idea of the Roman Empire as an existing utopia.
\end{abstract}

\section{INLEIDING}

Apokaliptiek is 'n term wat verskillende verwagtings by mense na vore bring. Hierdie verwagtings mond uit in gedagtes soos die vervanging van hierdie wêreld met 'n ander een. Die nuwe is 'n soort "utopiese" wêreld waarin 'n goddelike figuur uitkoms en regverdigheid sal bring. Dit vind ons by die gedagte van die koninkryk van God as 'n komende, transendente realiteit. Onlangse navorsing stel dit ook dat die voorstelling van die koninkryk van God in die Nuwe Testament as 'n apokaliptiese alternatief teenoor die Pax Romana-idee van die Romeinse keisers gedurende die vroeg-Christelike periode staan. Ek wil in hierdie studie probeer aantoon dat die koninkryk van God 'n begrip in die Nuwe Testament is wat verstaan kan word teen die agtergrond van die Pax Romana as 'n apokaliptiese begrip. Die apokaliptiese denke van die Romeinse politieke sisteem het 'n beduidende invloed gehad

\footnotetext{
*Hierdie artikel is gebaseer op Cules Boshoff se MDiv-skripsie, ingedien in 2003, onder leiding van prof dr Andries $\mathrm{G}$ van Aarde, Departement Nuwe-Testamentiese Wetenskap, Fakulteit Teologie, Universiteit van Pretoria.
} 


\section{Grieks-Romeinse apokaliptiek en die Christelike kerugma}

op die kerugma van Jesus en sy volgelinge. Die kerugma van die kerk is die bedding waarbinne die koninkryk van God as alternatiewe voorstelling van die Pax Romana gedien het. Die boodskap van Jesus vind dus neerslag in die apokaliptiese denke van die eerste-eeuse wêreld.

\section{DIMENSIES VAN APOKALIPTIEK}

Apokaliptiek is ' $n$ baie veelkantige term wat moelik definieerbaar is. Dit is selfs moontlik om te sê dat apokaliptiek in wese nie juis iets is nie, maar dat daar eerder dinge in ons ervaring lê wat ons apokaliptiek kan noem. Apokaliptiek verteenwoordig ten beste 'n reïnterpretasie van die verlede en hede in die lig van 'n nuwe toekoms. Schmithals (1973:22; kyk Boshoff 2001:567) beskryf dit as 'n spesifieke wêreld-, geskiedenis- en lewensbesef. Apokaliptiek is dus 'n allesomvattende godsdienstige perspektief van waaruit 'n goddelike plan in relasie tot die teenswoordige historiese situasie verstaan (Hanson 1979:2-3) en die verlede, hede en toekoms in 'n dualistiese en kosmiese raamwerk beskou word (Sim 1996:1).

Apokaliptiek is 'n bepaalde manier waarop die wêreld verstaan word. Die apokaliptiese toekomsbegrip word gebruik om die hede te kan hanteer en te oorleef terwyl die toekomstige wêreld nou iets word wat sin gee aan 'n desperate en moedelose hede. Eskatalogie is 'n term wat nou verband hou met apokaliptiek. Met die eerste oogopslag kan dit lyk asof beide teologiese begrippe, apokaliptiek en eskatalogie, eintlik op dieselfde betrekking het. Beide het te doen met die einde van die wêreld wanneer die Goedheid die Bose oorwin (Crossan 1998:259). Apokaliptiek en eskatalogie behoort egter duideliker onderskei te word. Volgens Crossan (1998:263) is eskatalogie die konsep waarin dit wat drasties verkeerd is met hoe die wêreld daaruit sien, beklemtoon word. Eskatalogie kom hiervolgens amper neer op 'n ontkenning van die huidige wêreld, dit wil sê die oortuiging daar iets diepgaande en radikaal verkeerd is, en dat dit slegs reg gestel kan word deur iets radikaal en teenoorgesteld.

Apokaliptiek en eskatalogie hoef dus nie altyd na die einde van die wêreld in 'n futuristiese, temporele sin te verwys nie. Dit kan metafories as 'n sinoniem vir beslissend of wêreld-veranderend gebruik word, sonder om noodwendig die einde van die geskiedenis aan te kondig. Vir Crossan (1998:283) beteken dit dat daar so 'n intense smagting is om ' $n$ ander wêreld te ervaar, dat daar nie meer deelgeneem kan word aan hierdie wêreld nie. 'n Apokalipties-eskatalogiese wêreldsiening is van mening dat die huidige wêreld met sy historiese en sosiale omstandighede nie meer bestaansreg het nie, sonder dat dit noodwendig verwys na die imminente einde van hierdie wêreld (Crossan 1998:285). Apokaliptiese eskatalogie het dus te doen met 
hoe om die krisisse in hierdie wêreld te kan hanteer en dit te oorleef. Dit gee aan die desperate en moedelose hede sin omdat 'n apokalipties-

eskatalogiese wêreldsiening die goddelike beheer oor die huidige omstandighede legitimeer (Sim 1996:70). Ten spyte van die huidige omstandighede het die gemarginaliseerde en onderdrukte groep die versekering dat God aan hulle kant is, dat hulle uiteindelik beloon sal word vir hulle volharding en dat hulle vyande gestraf sal word.

Die droom van 'n apokaliptiese wêreld is egter nie net beperk tot die gemarginaliseerdes en randfigure nie, maar vind ook neerslag in die gedagtegang van die maghebbers en wêreldmoondhede wat hulle "perfekte" wêreld ten alle koste moet handhaaf. Hierdie maghebbers sien hulleself gewoonlik as 'n soort van "messiaanse" beweging wat die wêreld moet red uit die chaos waarin dit verkeer. Apokaliptiek word hier die herlewing van die teologiese en politieke idees rondom die (her)bevestiging en (her)instelling van orde teenoor chaos (Georgi 1991:8). Wat hier 'apokaliptiek' genoem word is wat in die pre-moderne wêreld kosmogoniese mites was. Dit was mites wat die ontstaan en orde van die wêreld verklaar het aan die hand van allerlei godeverhale. Die maghebbers neem dit op hulleself om die wêreld te red uit die hande van die chaos om so 'n utopie te bewerk. Hulle beskou hulleself as die verteenwoordigers en bewaarders van die stabiliteit en orde. Daarom hoef apokaliptiese scenarios nie altyd gebruik te word om veranderinge aan te dui nie, dit kan ook gebruik word om die status quo te handhaaf (vgl Crossan 1998:262-267).

Die element wat apokaliptiek na vore gebring het, naamlik die vervanging van hierdie wêreld met 'n ander, volmaakte wêreld, wil dit hê dat hierdie vervanging gewoonlik katastrofaal en kataklismies moet wees. God se perfekte wêreld sal eers tot stand gebring kan word wanneer die sistemiese onreg en boosheid verwyder is. 'n Apokalipties-eskatalogiese perspektief op die einde van die wêreld impliseer dat dit wat geskep is tot 'n einde gebring sal word deur 'n kosmiese kataklisme waarin die totale skepping in duie stort. Hierdie ramp word uitgedruk in simboliese taal in die vorm van aardbewings, vallende sterre, donkerte in die daglig, leë grafte, heilige oorloë ensovoorts (Van Aarde 2001:1169).

So 'n apokaliptiese siening is egter om van slegs twee kante van die saak bewus te wees. Op 'n dualistiese wyse word onderskei tussen reg en verkeerd, die goddelike en die bose en tussen 'n wêreld hier en nou en 'n wêreld aan die anderkant (Van Aarde 2001:1171). So 'n apokaliptiese wêreldbeskouing word gekenmerk aan die een kant deur pessimisme en aan die anderkant deur hoop. Sulke pessimisme en determinisme word gerelativeer deur die oortuiging dat die gang van die geskiedenis verander kan word deur 


\section{Grieks-Romeinse apokaliptiek en die Christelike kerugma}

middel van gebede en die martelaarskap van die "regverdiges" (Sim 1996:54). Schmithals meen dat apokaliptiek die radikale pessimisme oor hierdie wêreld gelyk gee, maar die absolute moedeloosheid teenoor hierdie wêreld word tegemoet gekom deur die groot hoop op die komende en nuwe skepping voor te hou (Schmithals 1973:33-34). Die huidige bedeling is een van ongelukkigheid, onverdraagsaamheid en onderdrukking, maar dit sal vervang word met 'n transendente bedeling wat vreugdevol en ewig sal wees (Van Aarde 2001:1171).

Ten spyte van bogenoemde inligting behoort ons egter meer genuanseerd met apokaliptiek om te gaan. Alle apokaliptiek is nie altyd katastrofaal en kataklismies nie. Apokaliptiek kan ook ander dimensies aaneem. Om te bid kan apokalipties wees. Wanneer jy bid of mediteer, is jy eintlik besig met apokaliptiek omdat daar in die alledaagse wêreld tot stilstand gekom word en hierdie wêreld vervang word (al is dit net vir 'n oomblik) met God se wêreld. Gebed is dus 'n goeie voorbeeld hoe voorgestelde tyd ("sacral time") met ervaarde tyd ("profane time") oorvleuel (Malina 1996:192-193; Eliade [1987]).

Gedrag kan ook die wêreld tot 'n einde bring wanneer daar gepoog word om te stop om deel van hierdie wêreld te wees en 'n ander wêreld in te gaan. Sosiale of etiese apokaliptiek kan bewerk word deur asketisme, vas, seksonthouding of deur die normale bedrywighede van hierdie wêreld op te sê soos die eet van sekere kosse en die drae van sekere klere (Crossan 1998:274-289). Hierdie sosiale en kulturele gedrag is deur die Romeinse owerhede met agterdog bejeen omdat sulke gedrag 'n misnoeë met die status quo en die politieke orde te kenne gegee het. Sulke gedrag het die outoriteit van die politieke mag bevraagteken en dit was 'n bedreiging vir die sosiale norme, die kulturele tradisies en die voortbestaan van die Romeinse Ryk (Crossan 1998:236).

\section{PAX ROMANA}

Die Pax Romana - die Vrede van Rome, was die kern waarom die Romeinse keiser-families se beleid ten opsigte van 'n wêreldwye imperium gedraai het. Die Pax Romana is beskou as 'n gawe van die gode, 'n Ryk wat universeel en perfek in alle opsigte was (Rand 1943:78). Dit is beskou as die ideale Ryk wat die beginsels van ewigdurende geregtigheid, wet en orde, sekuriteit, voorspoed en vrede voorgehou het (Rand 1943:115). Die keisers, veral Augustus, is voorgestel as die eskatalogiese "redder van die ganse mensdom" (Koester 1992) en die "vader en beskermer van alle nasies" (Wengst 1987:48). Die keisers was dus die persone wat die ideale van die Pax Romana kom vervul het (Rand 1943:58). Hierdie ideale was die daarstelling van vrede en sekuriteit, 'n goeie regstelsel, materiële welvaart en 'n doeltreffende regering. 
Die Romeinse samelewing was besonder klas-georiënteerd. Drie faktore het hoofsaaklik die klasverdeling bepaal: (1) rykdom (of die gebrek daaraan), (2) vryheid (of die gebrek daaraan), en (3) Romeinse burgerskap. Hierdie klas- verskille is in stand gehou deur wetgewing. Een groep kon byvoorbeeld aanspraak maak op sekere politieke en wetlike voorregte, terwyl 'n ander groep hiervan uitgesluit was (Shelton 1988:4). Die klasverdeling het bygedra tot die orde en stabiliteit in terme waarvolgens die Romeinse Ryk georganiseer is.

Alhoewel die Romeinse Ryk 'n republiek genoem is, was dit vir alle praktiese doeleindes 'n aristokrasie wat deur die keiser regeer is (Shelton 1988:8). Die keiser het sy politieke mag gedeel met 'n klein groepie Romeinse elite wat bestaan het uit grondeienaars, politieke amptenare, burokrate asook militêre en godsdienstige leiers. Hierdie klein groep begunstigdes het ook die meeste ekonomiese voordeel getrek uit hulle noue verbintenis met die keiser. Die keiser is beskou as die grootste weldoener (patron) in die Romeinse wêreld. Die toegang en beheer wat hy gehad het oor hulpbronne soos grond, welvaart, status en eer, het van hom die rykste man in die Ryk gemaak (Joubert 2000:26). Dit is van die keiser, as patron van die nasie, verwag om voortdurend welwillendheid aan sy onderdane te bewys. Dit het geskied deur speles, sportbyeenkomste en selfs die uitdeel van geld aan die kleinboere wanneer 'n nuwe keiser aangewys word. Hierdie welwillendheid was 'n manier om sosiale stabiliteit en lojaliteit aan die keiser te verseker (Joubert 2000:26).

Volgens Carter (2001:10) kan die ekonomie van die Romeinse Ryk ten beste beskryf word as 'n "weermag-ekonomie" en dit is in stand gehou deur die Romeinse elite. Gevolglik was dit net die elite wat toegang tot rykdom, verowerde grondgebiede en sosiale status gehad het (Carter 2001:11). Die besit van grond het nie net welvaart en sosiale status vir die aristokrasie verseker nie, maar het ook beduidende mag oor ander mense se lewens beteken. Hierdie mag is uitgeoefen deur belastings en tariewe te hef en het die res van die bevolking van enige politieke en ekonomiese inspraak ontsê. Die aristokrasie het streng beheer hieroor uitgeoefen want wanneer belastings nie betaal word nie, sou dit lei tot die ineenstorting van die lewenswyse van die Romeinse elite wat weer die destabilisering van die Ryk tot gevolg sou gehad het.

Die politieke mag wat vrede en voorspoed veronderstel het was nou verweef met die Romeinse militêre mag. Dit het beteken dat daar nougeset en onmiddelik opgetree is teen enige moontlike bedreiging van buite die grense van die Romeinse Ryk, sowel as interne konflikte wat binne die grense van die Ryk kon ontstaan het (Wengst 1987:21). Vrede was die voertuig waarmee voorspoed, wedersydse verantwoordelikheid en burgerskap gekweek is wat 


\section{Grieks-Romeinse apokaliptiek en die Christelike kerugma}

alle inwoners saam moes bind (Wilken 1984:58). Vrede berus egter op harmonie en daarom het die Romeinse owerhede nie net baie klem gelê op die harmonie tussen die owerheid en die verskillende provinsies nie, maar ook op die harmonie tussen elke inwoner van die Ryk. Volgens Wengst (1987:21) kom die besonderse klem op harmonie, goeie wil en vriendskap eintlik neer op gehoorsaamheid aan, en erkenning van die Romeinse owerheid as die redder van die wêreld (in die persoon van die keiser).

Die absolute klem op harmonie en goeie burgerskap en die amperse sinisme waarmee die Romeinse owerhede dit opgedwing het, maak dit duidelik dat die vryheid en vrede van die Pax Romana inderdaad net vryheid en vrede vir Romeinse burgers was. Die stede in die provinsies, veral die Griekse stede, het net soveel vryheid gehad soos wat die Romeinse owerhede toegelaat het. Vir enige nie-Romeinse burger was die vryheid van die Pax Romana 'n vryheid wat onder Romeinse voorwaardes gegun was (Wengst 1987:22). Hierdie vrede en vryheid kan net behou word solank daar lojaal gebly word aan die Romeinse Ryk.

Die Romeinse vryheid en die vrede wat in stand gehou is deur militêre mag en geweld was inderdaad twee kante van dieselfde munt (Richardson 1991). Vir Carter (2001: 32) was die Pax Romana'n vrede wat instand gehou is deur militêre mag, gestalte gekry het in ekonomiese eksploitasie (belastings) en bekragtig is deur godsdienstige aansprake. Die vrede, vryheid en harmonie wat vanuit Rome, die middelpunt van die ryk, geproklameer is, het egter anders gelyk in die verskillende provinsies. Wengst (1987:24) haal Seneca aan waar hy sê dat die "werklike en ware deugde soos vryheid en vrede aan almal behoort. Dit behoort volledig aan elke individu en is ondeelbaar" (eie vertaling). Maar in die Romeinse praktyk was vryheid en vrede "deelbaar". Die uiteindelike voordeel van die Pax Romana, die "vrede en vryheid", was uiteindelik net beskikbaar vir 'n paar uitgelesenes, vir die res was dit net 'n "slagspreuk van die Romeinse Ryk" (Wengst 1987:24).

Die Pax Romana kan dus beskou word as 'n ekonomiese vrede wat die bestaande orde in stand moes hou en die status van die aristokratiese elite moes waarborg. Vir Rome was dit ook belangrik dat daar vrede en stabiliteit in die provinsies moes wees aangesien belastinggeld en ander ekonomiese middele daarvandaan gekom het (Wengst 1987:26). Die ekonomiese bydrae van die provinsies was dus die rede vir die aggresiewe instandhouding van die Pax Romana.

Die Romeinse Ryk was die tuiste van verskeie godsdienste, maar een spesifieke godsdiens is beskou as die ware godsdiens, die "godsdiens van ons vaders" (Shelton 1988:359) en dit was die staatsgodsdiens. Die Romeinse staatsgodsdiens moes die behoud en voorspoed van die Ryk 
verseker. Die bestaan van die staat het afgehang van die voortdurende nakoming van godsdienstige rites soos offers, goddelike verering en gebede. Hierdie rites was die erkenning van die mag van die gode en hulle instandhouding van die kosmos (Shelton 1988:370). Die gode het nie net die godsdiens beskerm nie, hulle beheer het ook die politieke en ekonomiese sfeer ingesluit, daarom het die staat die godsdiens beskerm.

In die Romeinse wêreld was daar geen onderskeid tussen die politieke en godsdienstige sfeer nie. Dit was ineenverweef. Romeinse keisers het dikwels godsdienstige rituele gebruik om politieke uitsprake te maak (Carter 2001 :20). Die gode het die regering van die Romeinse Ryk bekragtig en die keiser was die manifestasie van die soewereiniteit, goddelike teenwoordigheid en seën vanaf die gode. Die keiser was die tussenganger tussen die gode en die Ryk, en het die vrede, sekuriteit en voorspoed deur sy bewind oorgedra (Carter 2001:24). Die gode regeer die kosmos, en die keiser regeer die aarde. Die keiser is die regeerder, weldoener en vader van Rome en die mensdom, maar die gode is die beskermers en bewaarders van die Romeinse ryk. Die gode beskerm die Ryk, hou dit in stand en verseker die vrede en veiligheid van die wêreld deur die persoon van die keiser (Wengst 1987:47).

Die staatsgodsdiens en keiserkultus het die samebindende krag geword wat die Romeinse Ryk bymekaar gehou het. Dit het tot gevolg gehad dat almal in die Ryk lojaal moes wees teenoor die keiser en die staat (Wengst 1987:50). Dus, enige poging om te onttrek aan die aktiwiteite en godsdienstige rituele wat die doel gehad het om die keiser en die staat te huldig en te vereer, is onvermydelik met agterdog bejeën en as politieke dislojaliteit beskou (Wengst 1987:50).

\section{KONINKRYK VAN GOD}

Die sosiale wêreld van die eerste-eeuse Palestynse gemeenskap was dié van 'n "pre-industriële, agrariese gemeenskap" (Stegemann \& Stegemann 1999:104; vgl Borg 1995:966). Hierdie agrariese gemeenskappe het hoofsaaklik uit twee sosiale klasse bestaan: die regerende elite en die kleinboere (peasants) en dagloners. Die primêre bron van inkomste was landbou-aktiwiteite en omtrent twee derdes van alle inkomste het na die sakke van die stedelike elite gegaan (Borg 1995:967). Die ander derde van die inkomste is verdeel onder die kleinboere en dagloners. Israel was dus, net soos ander pre-industriële agrariese gemeenskappe, 'n gemeenskap wat verdeel was in 'n onderdrukkende stedelike elite en kleinboere wat uitgebuit is deur buitensporige belastings.

Die kleinboere kon slegs ekonomies oorleef as gevolg van sekere ekonomiese reëlings, soos die toegelate verbruik van sekere produkte, die 


\section{Grieks-Romeinse apokaliptiek en die Christelike kerugma}

gee van aalmoese en veral, die beginsel van weldoenerskap (patronage) (Malina 2001:31). Die begrip weldoenerskap was een van die boustene van die Romeinse samelewing. In 'n ekonomie waarin die meerderheid van hulpbronne aan 'n klein deel van die bevolking behoort het, was dit belangrik om verbind te wees aan 'n weldoener (patron) en so jou en jou familie se ekonomiese oorlewing te waarborg. Weldoenerskap behels die ruilhandel van onvergelykbare goedere en dienste tussen persone met ongelyke sosioekonomiese status. In 'n tipiese geval van weldoenerskap sal die persoon met die laer sosio-ekonomiese status (client) materiële middele soos voedsel, verblyf en klere ontvang terwyl die persoon met die hoër sosio-ekonomiese status (patron) op 'n minder tasbare wyse vergoed word in die vorm van persoonlike diens, onderwerping of lojaliteit (Malina 2001:31).

Weldoenerskap het gelei tot 'n skenk-en-skuld (gift-debt) verhouding tussen die persoon wat gee en die een wat ontvang. Weldoenerskap was 'n sisteem wat gemik was op sosiale beheer en oorheersing en het die wedersydse uitruil van goedere en dienste veronderstel. Volgens Joubert (2000:21) skep die uitruil van goedere en middele 'n ongelyke situasie tussen die twee partye. Die party wat gee, verkry outoriteit oor die ander een as die ander party nie in gelyke maat kan teruggee nie. Die skenk van middele en goedere was dikwels 'n doelbewuste poging om dominering en oorheersing moontlik te maak. As 'n party nie die geskenk in gelyke maat kan teruggee nie, is hy of sy ondergeskik aan die een wat gegee het en verloor hy of sy outoriteit en voordele ten koste van die weldoener (Joubert 2000:22). In agrariese gemeenskappe het die grondeienaar (patron) se status dikwels ooreengekom met dié van die weldoener en die kleinboere en dagloners (clients) wat afhanklik was van die grond en die grondeienaar om 'n bestaan te kon voer.

Malina (2001:33) vra die vraag waarom dit nodig geword het om 'n "Koninkryk van God" te verkondig? Hy antwoord hierdie vraag vanuit die sosiale agtergrond van die eerste-eeuse Israel. Die plaaslike aristokrasie en regerende elite in die onderskeie provinsies het namens die Romeinse owerhede opgetree as weldoeners (patrons), en so algaande die gebied in die groter Romeinse ideologie ingelyf sonder te veel ongerief in die lewens van die plaaslike bevolking. Belastings is in elk geval gehef, of dit gegaan het aan die plaaslike aristokrasie of aan 'n verafgeleë elite, dit was om te ewe vir diegene wat dit moes betaal.

Die "koninkryk van God" was die oplossing vir die ondraaglike situasie wat die Romeinse politieke ekonomie geskep het en ook entoesiasties deur die Israelse aristokrasie en elite bevorder is. Die aristokrasie het in gebreke gebly met hulle sosiale verantwoordelikheid en het deel gevorm van 'n 
korrupte politieke sisteem (Malina 2001:34). Die koninkryksgedagte is gesien as die imminente oplossing vir hierdie omstandighede. Die God van Israel sal weer beheer oorneem waar die aristokrasie gefaal het en God sal 'n nuwe politieke sisteem daar stel wat uitkoms sal bied aan alle armes, verdruktes en verontregtes. Die omgewing waaruit die gedagte van God se koningskap dus na vore kom, is dié van 'n dreigende opposisie wat oorwin moet word.

'n Nuwe koninkryk met 'n nuwe koning het tog bepaalde vrese by sommige kleinboere laat ontstaan omdat dit kon lei tot die ineenstorting van die sisteem van weldoenerskap in Israel. So 'n verlies sou noodwendig groter sosiale weerloosheid onder die kleinboere tot gevolg hê. In Jesus se koninkryksprediking is God nie net nog ' $n$ "monarg" nie, maar 'n "Vader" vir God se mense. In die politieke konteks van Rome was die titel "vader" 'n aanduiding van weldoener (patron) (Malina 2001:34). Die koninkryk van God het dus die propagering van 'n goddelike weldoenerskap behels. Die aankondiging van die koms van 'n Weldoener vir die hele mensdom het die valsheid van die Romeinse politieke sisteem blootgelê (Malina 2001:34). Die verkondiging van die koninkryk van God het die Israelse gemeenskap aangemoedig om die huidige wêreld te deurstaan en uit te sien na die toekoms met 'n nuwe politieke koninkryk waarin God heers (Malina 2001:142).

Die koninkryk van God kan egter nie losgedink word van die Messiasgedagte nie. Messianisme is die hoop op 'n verwagte figuur wat Israel polities sal bevry. Die koms van hierdie figuur vorm deel van die groter eskatalogiese wêreldbeeld waarin die bekende wêreld omgekeer sal word (Evans 2000:698) en vervang word met 'n nuwe, ideale wêreld waarin God die mag het. Die Messias- verwagting het die verlange na die ideale koningstipe verwoord. Messias en die koninkryk van God gaan hand aan hand en het ook te doen met die populêre beskouing oor koningskap in oud-Israel. Die koning moes ' $n$ baie sterk leër gehad het, hy is deur die hele volk verkies en was onderdanig aan sekere stipulasies van die verbond met God (Van Aarde 1994:140). Die koning moes die volk beskerm teen vreemde oorheersing en verdrukking en moes as waarborg dien vir die veiligheid van die volk (Van Aarde 1994:140). Die gesalfde van Israel sal diè een wees wat die juk van vreemde oorheersing kom afgooi. Jesus word in hierdie rol in vertolk. Hy word nie net die Messias wat die nood van sy lydende en verdrukkende volgelinge sien nie, maar ook die Een wat die ryk van God kom aankondig en sodoende aan alle lydendes uitkoms sal gee.

Die politieke ideologie van die Pax Romana het die sosiale wêreld waarbinne Jesus geleef het, beslissend beïnvloed. Jesus het self geleef in daardie deel van die bevolking wat aan die onderpunt van die Romeinse 


\section{Grieks-Romeinse apokaliptiek en die Christelike kerugma}

hiërargiese sisteem en die hiërargiese Jerusalemse tempel-ideologie moes oorleef. Hierdie was die persone wat kultureel, sosiaal en ekonomies "afgeskryf" is, dit was mense wat niks kon bied in ruil vir die beskerming van 'n weldoener nie en sonder enige sosiale eer was (Patterson 1998:64). Hulle was die bedelaars, melaatses, blindes, slawe en prostitute - almal mense wie se menswees niks meer in terme van die tempel- en die Romeinse politieke ideologie getel het nie.

Patterson (1998:69-82) wys daarop dat persone wat deur die Romeinse stelsel "afgeskryf" is, as onrein, sondig en sonder eer, beskou is. In die Israelse kultuur van Jesus het die gedagte van rein leef, nou saamgehang met die gedagte dat alles 'n plek en orde het. Enigiets wat uit plek en buite die orde is, is onrein. Bedelaars moes van aalmoese leef en dra enige kledingstuk wat hulle vind. Prostitute doen afstand van hulle eie behoeftes en begeertes en voldoen aan die begeertes van ander. Hierdie "afgeskryfdes" het hulle plek in die samelewing verloor en is daarom as onrein beskou. Hulle is ook as sondig beskou. Sonde, in die antieke wêreld het nie net 'n morele verbintenis gehad nie, maar ook 'n sosiale een. Enigiemand wat buite die grense van sosiale aanvaarbaarheid handel, soos bedelaars en prostitute, was sondig. Nie net was hulle sondig nie, maar ook sonder eer. Om eer te hê is om 'n plek te hê in die samelewing en om 'n plek te kry moet jy deur ander erken word. Die buitestaanders en "afgeskryfdes" het nie meer 'n plek in die samelewing gehad nie, en was daarom sonder eer.

Jesus verkondig God se koninkryk as 'n alternatief op die Romeinse sosiale sisteem (vgl Patterson 1998:83). Die koninkryk van God is die werklikheid in terme waarvan die Romeinse Ryk 'n parodie gevorm het (Horsley 2000:182). Jesus se beskrywing van die koninkryk verteenwoodig 'n alternatief op die sosiale strukture van hierdie wêreld waarin mense "ontmens" en "afgeskryf" was (Patterson 1998:93). Hy keer die sosiale en kulturele waardes wat hierdie wêreld gekonstitueer het, om. Jesus verhef diegene wat magteloos en onbelangrik was, die slagoffers van die sosiale waardes, tot die middelpunt van die koninkryk. Volgens Crossan (1998:317) is die aard van die koninkryk van God 'n koninkryk van "ongerekendes" en "ongewenstes". Dit was 'n koninkryk vir almal wat losgeraak het van die sosiale en familiale bande en haweloos ronddwaal. Jesus gee in die koninkryk van God weer 'n plek aan elkeen wat dit verloor het. Die koninkryk van God behoort dus aan elkeen wat sy plek in die sosiale organisasie van hierdie wêreld verloor het, melaatses, tollenaars, bedelaars, blindes, siekes en prostitute (Patterson 1998:86).

Dit is duidelik dat Patterson (1998:93) die koninkryk van God as 'n realiteit van hierdie wêreld sien. Die koninkryk waarvan Jesus praat is nie in 'n 
ander-wêreldse sfeer of verwyderd van die realiteite van hierdie lewe nie. Vir hom breek die koninkryk van God in die teenswoordige, bekende wêreld in. Jesus se woorde is tekenend hiervan "Hulle sal nie kan sê: 'Kyk, hier is dit!' of: 'Daar is dit!' nie, die koninkryk van God is hier by julle" (Luk 17:21). Ook vir Crossan dui die koninkryk op die lewe van hier en nou. Hy sien die koninkryk nie as 'n saak wat uitsluitlik na die hemel verwys nie, maar netsoveel na die aarde. Dit handel nie net oor die lewe hierna nie maar ook oor die teenswoordige werklikheid (Crossan 1998:239).

Tog behoort ons nie die inklusiwiteit in Jesus se optrede en evangelie as 'n bloot humanitêre en filantropiese beginsel te verstaan nie. Randfigure word nie as behorende tot God se koninkryk gereken bloot omdat hulle weerlose mense in 'n hiërargiese, uitbuitende samelewing was nie. Jesus se boodskap van inklusiwiteit behels meer as net sosiale etiek. Grondliggend aan die evangelie lê God se weldaad om onvoorwaardelik, afgesien van enige hiërargie of menslike konvensie of fisieke tekortkoming van die mens, vir enige mens tot hulp te wees. Die bekendmaking van hierdie weldaad word kerugma genoem.

\section{DIE KERUGMA VAN JESUS}

Kerugma is 'n Griekse woord wat aankondiging of bekendmaking beteken. In die Nuwe Testament verwys kerugma na 'n openbare bekendmaking of aankondiging waar die inhoud van hierdie boodskap die eskatalogiese redding van God deur die kruisiging en opstanding van Christus is (Johnson 1987:28-33). Kerugma is nie net die boodskap van verlossing wat op 'n spesifieke tyd en plek gebeur het nie, dit is veel eerder die middel waardeur die redding van God volvoer word. Vir Bultmann (1966:300) beteken dit dat die genade en redding van God ervaar word in die evangelie wat nou verkondig word. Kerugmatiese toespreke word gehoor en toegeëien wanneer die mens eksistensieel daarby betrokke is. Kerugma artikuleer nie menslike konvensies nie en het ook nie die bedoeling om die mens as objek, ingebed in die konteks van menslike konvensies, 'n "beter" mens te maak nie. Kerugma transendeer dooie letters tot kragtige woorde van God se Gees. Dit is nie voorwerplik van aard nie en daarom nie vir voorwerplike denke bewysbaar nie (kyk Van Aarde 2003:46 se bespreking van Bultmann se hermeneutiese program).

Wat hiermee bedoel word is dat in die voor-wetenskaplike mitologiese wêreld, God se betrokkenheid by mense van die eerste eeu, voorwerplik geformuleer is in terme van mitiese taal. Mitiese taal is voorwerplike spreke waarin God se doen en late in objektiverende taal beskryf en verduidelik word. God word deur mense verstaan na analogie van iets anders in die skepping, 


\section{Grieks-Romeinse apokaliptiek en die Christelike kerugma}

terwyl God nie deel van die skepping en objektiveerbaar is nie. Teologie se taak is dus om God te "ont-objektiveer", dit wil sê te ontmitologiseer. In die kerugma vind hierdie proses plaas. Die aanbod van God om genade geskied in 'n historiese gebeure. Die eis van God dat mense hulle met God moet versoen geskied nie in 'n vakuum nie, maar te midde van historiese gebeure. Dit geskied, in die eerste plek in die persoon van Jesus van Nasaret wat aan ons verkondig word. Maar die historiese Jesus is nie vir ons voorhande nie alleen die Christus. In die kerugma word die mitiese spreke wat getuig van 'n vroeëre mitologiese wêreld ontmitologiseer. Die historiese mens Jesus se woorde en dade was ingebed in die mitologiese dinkwêreld van sy tyd. 'n Deel van hierdie vroeëre mitologiese wêreld was die apokaliptiese spreke. Die boodskap van Jesus vind neerslag in die apokaliptiese denke van Jesus waar apokaliptiek 'n sosiale en etiese dimensie aangeneem het. Die kerugma oor Jesus vertolk hierdie historiese gebeure in terme van ons dinkwêreld vandag. Kerugma word gehoor en geleef wanneer ons in verhouding met God staan. Kerugma word gehoor wanneer die voorwerplikheid van die vroeëre spreke getransendeer word. So word die objektiverende taal oor God se koninkryk as alternatief op die Pax Romana hermeneuties in hedendaagse kategorieë vertaal.

Die mens is nie daartoe in staat om hom- of haarself te verlos van hierdie wêreld en die magte wat die mens daartoe bind nie. Dit is iets wat moet gebeur van buite af en kan slegs geskied vanaf die goddelike wêreld. Bultmann (kyk Johnson 1987:192) meen dat die Christelike geloof presies dit laat gebeur het in die persoon van Jesus van Nasaret. Die persoon van Jesus word deur invloedryke volgelinge van Jesus in die vroegste kerk (soos byvoorbeeld Paulus en Johannes) in terme van so 'n verlossingsmite geinterpreteer. Hierdie mite het die bedding gevorm waarin die persoon en werk van Jesus verstaanbaar gemaak kon word as 'n teenswoordige realiteit. Sy koms is die aankondiging van die eskatalogiese gebeure wat die einde van die wêreld aankondig. Hy is 'n goddelike figuur wat vanaf die Vader in die hemelse wêreld van die lig, gestuur is na die aardse wêreld om hier verlossing te kom bewerk. Deur Jesus word die eskatalogiese gebeure gerealiseer in die hede (Johnson 1987:192). Jesus word nou, na aanleiding van 'n kosmiese voorstelling, die eskatalogiese redder wat die "ou" wêreld kom vervang en 'n "nuwe" wêreld instel (Johnson 1987:193). Die verhaal van die Christelike verlosser is dus gevorm in die mitologiese idioom van die tyd.

Jesus se redding het egter die vorm aangeneem van verwerping, lyding en dood. Die volgelinge van Jesus het Hom na sy dood beskryf as iemand wie se woorde en dade dié is van iemand wat alreeds 'n nuwe lewe lei. Volgens Koester (1992:9) is die kerugma van Jesus in die lig van sy 
kruisdood gebruik as 'n politieke boodskap waarin die politieke eskatalogie van die Romeinse ryk uitgedaag is. Die vroeë Christelike gemeenskappe het Jesus verkondig as die vors van die nuwe era wat die slagoffer was van 'n korrupte politieke orde.

Die politieke regering van Rome was gebaseer op 'n ideologie van 'n gerealiseerde eskatalogie waarin die nuwe wêreld onder keiser Augustus aangebreek het. Hierdie Romeinse eskatalogie het bepaalde kenmerke gehad: (1) Die nuwe era onder Augustus is die vervulling van die Romeinse profesieë. (2) Die nuwe era sluit die aarde en die hemele in. Apollo is die god van die nuwe era. (3) Hierdie nuwe era is universeel en sluit alle nasies en stede in die ryk in. (4) Die waarborg van die nuwe goddelike era word bevestig deur die viering van die keiserlike feeste en speles. (5) Die nuwe era is gebou op die mitiese verhale van 'n reddende figuur, die grootste weldoener van alle tye en die divi filius (seun van God), te wete keiser Augustus (Koester 1992:12-13).

Koester (1992:13) wys daarop dat Jesus 'n "slagoffer" van hierdie wêreld en sy politieke magte was. Na die dood van Jesus moes sy volgelinge die vraag antwoord: Wie was hierdie persoon op wie se kruis gestaan het: "Jesus van Nasaret. Koning van die Jode"? Hulle antwoord was eenparig: Jesus was die "slagoffer" van die wêreld - 'n wêreld waarvan Jesus die einde aangekondig het. $\mathrm{Na}$ Jesus se dood word Hy verkondig as die een wat opgestaan het uit die dood, wat lewe en wat by sy volgelinge teenwoordig is in die vorm van die Heilge Gees (Koester 1992:13). Die volgelinge van Jesus het geglo dat die nuwe wêreld aangebreek het op grond daarvan dat sy verwerping, lyding en kruisdood sy boodskap bevestig het. Singewing is nie meer in hierdie-wêreldse sisteme en konvensies te vinde nie, maar breek deur in die toekomstige wat reeds in hierdie wêreld manifesteer. Die kerugma van Jesus se volgelinge was ook eskatalogies gekleur. Die eskatalogiese gebeure het egter met die koms van Jesus in die hede gerealiseer. Dit verwys na ' $n$ toekoms wat drasties sal verskil van die politieke ryk en ideologie waarvan Jesus die slagoffer was - 'n toekoms waarin Jesus die teenswoordige werklikheid reeds gedeel het.

$\mathrm{Na}$ die dood van Jesus het sy navolgers besef dat Jesus se historiese bestaan van min betekenis is as die inhoud van sy bestaan nie ook bekend is nie. Die inhoud van sy bestaan, sy kerugma, is die koninkryk van God wat verkondig word as die konstituering van 'n nuwe gemeenskap, 'n nuwe politieke orde en - inderdaad - 'n nuwe wêreld wat reeds aangebreek het. Dit is egter belangrik om daarop te let dat hierdie koninkryksopvattinge diverse vorme aangeneem het onder die Jesusbeweging, die vroeë kerk asook die evangelieskrywers. 


\section{Grieks-Romeinse apokaliptiek en die Christelike kerugma}

Jesus se prediking het ten doel gehad om 'n alternatiewe wêreldbeskouing te verkondig. Die kerugma van Jesus behels om ander te dien, eerder as om oor hulle te heers (Mark 10:42-44). Om aan diegene geld te leen wat dit nie kan terugbetaal nie (Luk 6:34). Om jou vyand lief te hê (Luk 6:27). Om iemand se goed twee myl te dra in plaas van een (Matt 5:41). Om die wang te draai (Matt 5:39). Om eerder te bid in plaas van aanval en om mense van alle nasies uit te nooi om deel te hê aan die feesmaal (Luk 13:28-29). Dit is die koninkryk van God - oop vir enigeen, veral vir die randfigure, maar nie op grond van 'n filantropiese beginsel nie, maar omdat God se betrokkenheid by en liefde vir die randfigure ' $n$ voorbeeld is van hoe onvoorwaardelik God se genade manifesteer.

\section{BEVINDING}

Die Romeinse Ryk se eskatalogiese redding het aangebreek in die Pax Romana. Die Pax Romana was die vervulling van die profesieë, dit het die hemel en die aarde ingesluit en het gerealiseer deur Augustus - die "redder van die mensdom". Dit was 'n eskatalogiese ryk wat pretendeer het om vrede en sekuriteit aan almal op aarde te bied. Die Romeinse heerskappy is gesien as 'n tipe "messiaanse" beweging wat die wêreld moes red uit die chaos waarin dit verkeer het. Die redding het gepaard gegaan met die skep van 'n perfekte wêreld in volledige harmonie met die regering van die gode. Die Pax Romana was die realisering van die transendente wêreld van die gode. Dit was ' $n$ wêreld wat nuut aangebreek het en tot voordeel van almal moes wees. Die Pax Romana was dus in wese apokalipties. Dit het nie 'n nuwe wêreld in die toekoms verwag nie - die nuwe wêreld het reeds onder Augustus aangebreek.

Die konsep van die koninkryk van God het as konsep ontstaan in veral die narratiewe wêreld van die Israelse apokaliptiese geskrifte. Hierdie geskrifte het 'n kosmiese eskatalogie voorgehou waarin hierdie wêreld vervang sal word met 'n ander wêreld. In die Israelse apokaliptiek is die koninkryk van God 'n apokaliptiese gebeure wat deur 'n kosmiese katasrofe voorafgegaan sal word. Hoe meer die desperaatheid en trauma in hierdie wêreld, hoe groter sal God se uiteindelike ingrype wees. Die primêre boodskap van die Israelse apokaliptiek het gefokus op 'n toekomstige ingrype van God waar die onderdrukkende regime geoordeel en vernietig sal word. Die slagoffers van hierdie verdrukking sal herstel word en diegene wat gely het, sal opgewek en verheerlik word (Crossan 2003). Die Israelse apokaliptiek verwag nog 'n verlosser, in die vorm van die Messias, wat die verlossing sal bring. 
Hierdie studie het gepoog om aan te toon dat die koninkryk van God beskou kan word as 'n alternatief op die Pax Romana. Die koninkryk van God het die Pax Romana kom vervang en die vervanging vind plaas deur die kerugma. Die kerugma is die bedding waarbinne die Koninkryk van God die Pax Romana vevang. Alhoewel die koninkryk-gedagte uit die Israelse apokaliptiese denke ontstaan het, is dit nie meer net ' $n$ toekomstige werklikheid nie. Die kerugma van die kerk verkondig die koninkryk as alreeds teenwoordig in hierdie wêreld. Ek wil op grond van hierdie studie beweer dat die Christelike gedagte van die koninkryk as teenswoordige werklikheid ontleen is aan die gedagte van 'n gerealiseerde utopie in die vorm van die Romeinse Ryk. Die Pax Romana het ' $n$ harmonie met die gode nagestreef. Dit het vrede en stabiliteit voorgehou, dit was universeel en is regeer deur die "seuns van die gode". Die koninkryk van God is 'n alternatief op die Pax Romana en dit manifesteer nie in 'n ander-wêreldse sfeer nie, maar in hierdie wêreld. Jesus verkondig God met die politieke terme van die Romeinse ryk. God is die enigste "redder van die mensdom", God is die "vader' en "koning" van die nuwe koninkryk wat alreeds aangebreek het. God is die "weldoener" wat vir ewig sal sorg.

Hierdie terme dui op 'n ryk wat in hierdie wêreld teenwoodig is. In die Christelike godsdiens het ' $n$ element van die Israelse apokaliptiek agtergebly. Alhoewel die koninkryk van God reeds teenwoordig is, is daar tog nog die verwagting van die wederkoms waarin Jesus voorgestel word as die eskatalogiese redder wat die dooies sal opwek (Joh 5:28; 1 Tess 4:16) en die finale oordeel sal fel (Op 1:3). Die Christelike kerugma het dus aan die een kant die gerealiseerdheid van die Pax Romana oorgeneem en aan die anderkant die apokalipties-eskatalogiese verwagting van die Israelse apokaliptiek behou.

Ek wil die kerugma van Jesus illustreer aan die hand van die gelykenis van die saaier (Mark 4:2-20).

Luister hier! 'n Saaier het eendag gaan saai. Met die saai het 'n deel van die saad op die pad geval, en die voëls het gekom en dit opgepik. 'n Ander deel daarvan het op die klipbank geval, waar daar nie baie grond was nie. Dit het gou opgekom, omdat die grond nie diep was nie. Maar toe die son warm word, is dit verskroei, en omdat dit nie wortel geskiet het nie, het dit verdroog. 'n Ander deel het tussen die onkruid geval. Die onkruid het opgekom en dit laat verstik, en dit het nie saad geskiet nie. Die ander saad het in goeie grond geval, en dit het opgekom, gegroei en 'n oes gelewer. Party het dertigvoudig gedra, ander sestigvoudig en nog ander honderdvoudig. 


\section{Grieks-Romeinse apokaliptiek en die Christelike kerugma}

Hierdie gelykenis is nie 'n allegorie nie, Jesus lê dit net allegories uit. In hierdie gelykenis het ons te doen met apokaliptiese beelde uit die landbou. Soortgelyk vertel Papias 'n storie van 'n wingerd wat in oormaat vrug gedra het (Scott 1989:356-357). Die koninkryk van God kan vergelyk word met 'n wingerdstok wat geplant word en so groei en vertak dat dit oorgaan in tientalle vermeerderings. Tien is die apokaliptiese getal vir volmaaktheid (Collins 1996:140; Van Aarde 2002:1172). Die wingerdstok vermeerder in terme van tien takke met elke tak tien lote en elke loot tien trosse. Die wingerstok dra in oormaat vrug.

In die gelykenis van die saaier vind ons ook tien in vermeedering wanneer die oes gelewer word en party "dertigvoudig, ander sestigvoudig en nog ander honderdvoudig" gedra het. Die fokus in hierdie gelykenis is op die saad en wat daarvan word, nie op die saaier nie (Scott 1989:351). Dwarsdeur die gelykenis is die saad die middelpunt. Met die eerste saai val die saad op die pad en word dit deur die voëls opgepik. Die tweede hand se saad het darem opgekom, maar verdroog en die derde hand het verstik tussen die onkruid. Na drie keer wat die saad nie kon wortel skiet nie, is daar uiteindelik sukses. Drie oeste misluk, maar die vierde een is suksesvol. Tog is die opbrengs van die oes nie buitensporig nie maar alledaags en gewoon. In hierdie gelykenis is daar drie keer mislukkings en net een keer sukses. Misoeste en teleurstellings is onvermydelik deel van enige landbou-aktiwiteit. Juis in die mislukking en alledaagsheid van hierdie wêreld breek die koninkryk van God aan (Scott 1989:361). Volgens Jesus is die koninkryk van God nie soos die Pax Romana 'n perfekte, ander-wêreldse utopie nie. Na groot verwagtings rondom 'n oorvloedige oes, is die oes maar net gewoon en alledaags. God se koninkryk transendeer die gewone alledaagse lewe.

In die gelykenis word die hoorder gekonfronteer met ' $n$ koninkryk waarin mislukking en alledaagsheid deel is. Dertig is 'n oneweredige getal en vermeeder na sestig. Sestig is twee keer dertig; so die logiese volgorde moet honderd en twintig wees. Jesus gebruik egter honderd om die reëlmaat van onreëlmatige getalle te breek. Hiermee wil Jesus sê dat die koninkryk van God ook daar is waar die Woord van God as 't ware verstik en die groei onreëlmatig is. Die koninkryk van God is daar waar sukkelende groei is. Dit is net so paradoksaal soos die evangelie dat lewe op grond van die kruisdood moontlik is (Mark 8:34-9:1). Die honderdvoudige saad wat groei te midde van alle verstikkende faktore wys op die "volmaaktheid" van die koninkryk van God te midde van onvolmaaktheid. Die onreëlmatigheid wys op die diaforiese groei van die koninkryk (Scott 1989:362). Die lewe in hierdie wêreld word gekenmerk deur hortende onreëlmaat, maar die koninkryk van God breek hierin in volledigheid aan. 


\section{Literatuurverwysings}

Aune, D E 1986. The apocalypse of John and the problem of genre. Semeia 36, 1319.

Boshoff, P B 2001. Apokaliptiek en eskatalogie: Die verband en onderskeid volgens Walter Schimthals. HTS 57, 563-575.

Bowley, J E 2000. s v Pax Romana. Dictionary of New Testament Background.

Borg, M J 1995. Jesus and politics in contemporary scholarship. HTS 51, 962-995.

Burden, J J \& Prinsloo W S (reds) 1987. Tweegesprek met God: Die literatuurvan die Ou Testament, Deel 3. Kaapstad: Tafelberg.

Bultmann, R [1966] 1966. Faith and understanding, tr by L P Smith. London: SCM.

Carter, W 2001. Matthew and empire: Initial explorations. Harrisburg, PA: Trinity.

Collins, A Y 1979. Early Christian apocalypses. Semeia 14, 61-69.

Collins, A Y 1986. Introduction: Early Christian apocalyptism. Semeia 36, 1-12

Collins, A Y 1996. Cosmology and eschatology in Jewish and Christian apocalyptism. Leiden: Brill.

Crossan, J D 1998. The birth of Christianity: Discovering what happened in the years immideately after the execution of Jesus. San Fransisco, CA: Harper SanFransisco.

Crossan, J D 2003. The resurrection of Jesus in its Jewish context. Neotestamentica. (forthcoming.)

Eliade, M 1987. Die magie van het alledaagse: De transcendentie van het dagelijks leven, vertaal deur $\mathrm{H}$ Andrews. Katwijk: Srvire.

Eliade, M 1999. De grote mythen van den wereld. Leuven: Dawidsfonds.

Evans, C A 2000 s v. Messianism. Dictionary of New Testament Background.

Georgi, D [1987] 1991. Theocracy in Paul's praxis and theology, tr by D E Green. Minneapolis, MN: Fortress Press.

Hanson, P D 1979. The dawn of apocalyptic: The history and sociological roots of Jewish apocalyptic eschatology. Philadelphia, PA: Fortress.

Horsley, R A (ed) 1997. Paul and empire: Religion and power in Roman imperial society. Harrisburg, PA: Trinity.

Horsley, R A (ed) 2000. Paul and politics. Harrisburg, PA: Trinity.

Jesus Seminar 2000. The once and future Jesus. Santa Rosa, CA: Polebridge.

Johnson, R A 1987. Rudolf Bultmann: Interpreting faith for the modern era. San Fransisco, CA: Collins.

Joubert, S 2000. Paul as benefactor: Reciprocity, strategy and theological reflection in Paul's collection. Tubingen: Mohr Siebeck. (Wissenchaftliche Untersuchen zum Neuen Testament 2 Reihe 124.)

Koester, H 1992. Jesus the victum. Journal of Biblical Literature 111(1), 3-5.

Malina, B J [1989] 1996. Christ and time: Swiss or Mediterranean?, in Malina B J, The social world of Jesus and the Gospels, 179-214. London: Routledge.

Malina, B J 2001. The social gospel of Jesus: The Kingdom of God in Mediterranean perspective. Minneapolis, MA: Fortress Press.

Nel, M \& Human, D J 2002. Historiese en sosiale oorsprong(e) van apokaliptiek. HTS 58, 1056-1075.

Patterson, S J 1998. The God of Jesus: The historical Jesus and the search for meaning. Harrisburg, PA: Trinity. 


\section{Grieks-Romeinse apokaliptiek en die Christelike kerugma}

Petit, P 1967. Pax Romana, tr by J Wills. California, CA: University of California Press.

Rand, E K 1943. The building of eternal Rome. Cambridge, MA: Harvard University Press.

Richardson, J S 1991. Imperium Romanum: Empire and the language of power. Journal for Roman Studies 81, 1-9.

Rist, M 1989 s v. Apocalyptism. IDB, Vol 1.

Shelton, J 1988. As the Romans did: A sourcebook in Roman social history. Oxford: Oxford University Press.

Schmithals, W 1973. Die Apokalyptik: ein Führung und Deutung. Göttingen: Vandenhoeck. (Sammlung Vandenhoeck.)

Scott, B B 1989. Hear then the parable: A commentary on the parables of Jesus. Minneapolis, MN: Fortress.

Sim, D C 1996. Apocalyptic eschatology in the Gospel of Matthew. Cambridge, UK: Cambridge University Press. (SNTS Monograph Series.)

Stegemann, E W \& Stegemann, W [1995] 1999. The Jesus Movement: A social history of its first century, tr by O C Dean. Edinburgh: T\&T Clark.

Van Aarde, A G 1994. Kultuurhistoriese agtergrond van die Nuwe Testament: Die eerste-eeuse Mediterreense sosiale konteks. Pretoria: Kital.

Van Aarde, A G 2001. Millenialisme, eskatalogie en apokaliptiek. HTS 57, 11581178.

Van Aarde, A G 2002. Die "evangelie" van Paulus. Verbum et Ecclesia 23, 516-531.

Van Aarde, A G 2003. Teologiese Hermeneutiek. Ongepubliseerde kernaantekeninge. Universiteit van Pretoria.

Van Aarde, A G 2003. Theorizing about myths. Acta Patristica et Byzantium 14.

Wengst, K [1986] 1987. Pax Romana and the peace of Jesus Christ, tr by J Bowden. London: SCM.

Wilken, R L 1984. The Christians as the Romans saw them. New Haven: Yale University Press. 